\title{
The Debate Between the European Parliament and the Commission on the Definition of Protected Designation of Origin: Why the Parliament Is Right
}

\author{
Andrea Zappalaglio
}

Published online: 7 March 2019

(C) The Author(s) 2019

\begin{abstract}
On 1 June 2018 the EU Commission presented a Proposal for the reform of the EU CAP, including different aspects of the EU sui generis GI rules. In particular, this Institution has put forward an amendment to the definition of protected designations of origin (PDO), according to which the "human element" of the link between the product and the place, that has always been a key part of the concept of appellation of origin/PDO, should become optional, to be taken into consideration only "when relevant". Allegedly, this amendment should enhance clarity and simplicity within the EU GI system. The present opinion disagrees and invites the Commission to reconsider the proposed reform. Indeed, on the one hand, this seems to be based on a disputable notion of the PDO origin link; on the other, it is likely to have a modest impact on the structure of the applications as the human element will always be relevant in order to establish a convincing terroir link. Thus, the goals that the Commission is determined to pursue - namely, the simplification of the system and the acceleration of the registration procedure - will hardly be achieved. More specifically, this opinion submits that this specific amendment concerning the definition of a PDO should not be included in the future reform of the EU Law of Geographical Indications because: (1) it is based on an idea of GI protection that was discarded with the introduction of the EU sui generis GI regime in 1992; (2) it adopts a disputable concept of terroir; (3) it could potentially weaken the foundations of PDO and makes it less justifiable with respect to third countries; and (4) it is apparently inconsistent with the recent reform of the Lisbon Agreement, that the Commission itself is endorsing and recommending to the EU Member States.
\end{abstract}

This opinion has been developed within the context of the work of the Max Planck GI Research Team. Special thanks to Flavia Guerrieri and Dr. Suelen Carls for their valuable feedback.

\footnotetext{
A. Zappalaglio $(\bowtie)$

DPhil (Oxford), LL.M. (London); Senior Research Fellow at the Max Planck Institute for Innovation and Competition Law, Munich, Germany

e-mail: andrea.zappalaglio@ip.mpg.de
} 
Keywords EU GI Law - Appellations of origin - Common agricultural policy · Protected designation of origin (PDO) - Protected geographical indication (PGI)

\section{Introduction}

On 1 June 2018 the European Commission published a proposal for a Regulation of the European Parliament and of the Council (hereafter, the "Proposal") ${ }^{1}$ aimed at pursuing a wide-ranging reform of various aspects of the EU Common Agricultural Policy (hereafter, the "CAP"). ${ }^{2}$ In this broad context the Commission has also put forward different amendments to Regulation 1151/2012 on quality schemes for agricultural products and foodstuffs (hereafter the "Regulation"). ${ }^{3}$

In particular, the European Commission proposes to amend the definition of Protected Designation of Origin (hereafter, "PDO") provided under Art. 5(1) of the Regulation, which currently reads as follows:

For the purpose of this Regulation, "designation of origin" is a name which identifies a product:

(a) originating in a specific place, region or, in exceptional cases, a country;

(b) whose quality or characteristics are essentially or exclusively due to a particular geographical environment with its inherent natural and human factors; and

(c) the production steps of which all take place in the defined geographical area.

The Commission suggests that letter (b) of the current definition should be modified as follows: “(b) whose quality or characteristics are essentially or exclusively due to a particular geographical environment, with its inherent natural factors and where relevant human factors". 4

Appearances aside, the proposed amendment is highly relevant and cannot go unnoticed, as it concerns the heart of a sui generis GI right, i.e. the substantive nature of the link between a product and its place of origin (hereafter, the "origin link"). Indeed, the existence of this link is what distinguishes sui generis rules for the protection of geographical names from the broader family of quality labels, i.e.

\footnotetext{
${ }^{1}$ The European Commission (2018) Proposal for a Regulation of the European Parliament and of the Council amending Regulations (EU) No 1308/2013 establishing a common organisation of the markets in agricultural products, (EU) No 1151/2012 on quality schemes for agricultural products and foodstuffs, (EU) No 251/2014 on the definition, description, presentation, labelling and the protection of geographical indications of aromatised wine products, (EU) No 228/2013 laying down specific measures for agriculture in the outermost regions of the Union and (EU) No 229/2013 laying down specific measures for agriculture in favour of the smaller Aegean islands. COM(2018) 394 final.

${ }^{2}$ For more information on the EU Common Agricultural Policy, see the European Commission (2012) The Common Agricultural Policy: A Partnership between Europe and Farmers.

${ }^{3}$ Regulation No 1151/2012 of the European Parliament and of the Council of 21 November 2012 on quality schemes for agricultural products and foodstuffs [2012] L343/1.

${ }^{4}$ Supra note 1, p. 31. Emphasis added.
} 
labels that provide information on how the goods were made but not necessarily where. ${ }^{5}$ This element is so important that the definitions of various regimes of sui generis indications of geographical origin often coincide with the definition of the nature of the origin link itself. The most important example of this is offered by the definition of "Geographical Indications" enshrined in Art. 22(1) of the TRIPS Agreement:

Geographical indications are, for the purposes of this Agreement, indications which identify a good as originating in the territory of a Member, or a region or locality in that territory, where a given quality, reputation or other characteristic of the good is essentially attributable to its geographical origin. ${ }^{6}$

As will be better explained below, ${ }^{7}$ the PDO quality scheme descends from the French Appellation d'Origine Contrôllée (hereafter, "AOC") and from the Appellation of Origin model (hereafter, "AO") introduced, in 1958, to the international legal framework by the Lisbon Agreement for the Protection of Appellations of Origin (hereafter, the "Lisbon Agreement"). ${ }^{8}$ Both of those models are based on the concept of terroir and consider the origin link as a mix of natural and human factors. In line with its forbearers, and from the beginnings of the EU sui generis GI regime, as it was introduced in $1992,{ }^{9}$ the origin link of a PDO has always been defined as a combination of those two factors. Here, for the first time ever, the Commission seems interested in stressing the physical/environmental element while turning the human contribution into an optional element that could be added to the specification "where relevant".

The European Parliament, however, opposes this proposed new text and, in a report, the Committee on Agriculture and Rural Development has put forward the following version of Art. 5(2)(b) of the Regulation: "whose quality or characteristics are essentially or exclusively due to a particular geographical environment, with its natural and human factors." 10

\footnotetext{
${ }^{5}$ See Barham (2016), pp. 53-54 and Barham (2002), pp. 352-354. See also Barham (2003), pp. 129-131.

${ }^{6}$ Emphasis added.

7 See infra Section 2.2.

8 The WIPO, The Lisbon Agreement for the Protection of Appellations of Origin and their International Registration (31 October 1958, as revised in Stockholm on 14 July 1967 and as amended on 28 September 1979).

${ }^{9}$ Cf. Council Regulation No 2081/92 of 14 July 1992 on the protection of geographical indications and designations of origin for agricultural products and foodstuffs [1992] L208/1, Art. 2(2)(a) “(...) the quality or characteristics of which are essentially or exclusively due to a particular geographical environment with its inherent natural and human factors, and the production, processing and preparation of which take place in the defined geographical area." Emphasis added.

${ }^{10}$ EU Parliament Committee on Agriculture and Rural Development, draft report on the proposal for a Regulation of the European Parliament and of the Council amending Regulations (EU) No 1308/2013 establishing a common organisation of the markets in agricultural products, (EU) No 1151/2012 on quality schemes for agricultural products and foodstuffs, (EU) No 251/2014 on the definition, description, presentation, labelling and the protection of geographical indications of aromatised wine products, (EU) No 228/2013 laying down specific measures for agriculture in the outermost regions of the Union and (EU) No 229/2013 laying down specific measures for agriculture in favour of the smaller Aegean islands [2018] 2018/0218(COD), p. 69.
} 
It can be observed that the Parliament does not accept the addition "when relevant" and, moreover, it proposes cutting the adjective "inherent" from the clause "inherent natural and human factors" in the current version of the text. The Committee explains this counterproposal as follows:

This amendment calls for the definition of designation of origin to be maintained by adapting it to the Lisbon Agreement. Human factors are indeed essential in the characterisation of a product with a protected designation of origin. Alleviating the human factors would moreover affect the protection of products at international level where opponents will often evoke similarities in the natural and geographical environment to undermine the specificity of designations of origin. ${ }^{11}$

The opinion set forth in this article sides with the European Parliament. In fact, it will be shown that the Proposal put forward by the Commission may prove counterproductive for EU GI law for various reasons, both practical and theoretical. In particular, it is likely to be detrimental to the nature of PDO, in the worst-case scenario, or just superfluous, in the best-case scenario.

This statement will be supported in the following way: first the concept of PDO and its historical origins will be discussed; second the justificatory reasons for the Commission's proposal will be analysed; third, and final, it will be demonstrated that the proposed amendment is problematic because (1) it is based on an outdated idea of GI protection; (2) it seems to misinterpret the concept of terroir; (3) it is very likely that it would weaken the foundations of the PDO quality scheme; and (4) it is inconsistent with the recent reform of the Lisbon Agreement that the EU Commission itself is actively supporting and endorsing.

\section{Protected Designation of Origin: Concept and Roots}

\subsection{The Concept of PDO and PGI Under Art. 5 of Regulation 1151/2012}

Before turning to the reasons why the proposed reformulation of the definition of PDO should be reconsidered, it is important to analyse, first of all, what this quality scheme is. It is one of the two quality schemes provided by Regulation 1151/2012, the other being the protected geographical indication (hereafter, "PGI"). As mentioned in the introduction to this article, Art. 5 of Regulation 1151/2012 defines PDOs as names distinguishing products that are "essentially or exclusively due to a particular geographical environment with its inherent natural and human factors". 12 This kind of link is often defined with the French term terroir. This will be better analysed below. ${ }^{13}$ This origin link substantially distinguishes PDO from PGI, which Art. 5(2) of Regulation 1151/2012 defines as follows:

\footnotetext{
11 Ibid.

12 Art. 5(1) of Regulation 1151/2012.

13 Infra Sub-subsection 4.2.1.
} 
[...] a name which identifies a product:

(a) originating in a specific place, region or country;

(b) whose given quality, reputation or other characteristic is essentially attributable to its geographical origin; and

(c) at least one of the production steps of which takes place in the defined geographical area.

It can be observed that PGI rules are significantly less demanding. First of all, this emerges from the geographical requirement. Indeed, as stipulated by letter (c), only one step of the production must be completed in the designated area. By contrast, PDO requires all of the steps to be carried out in the place of origin, including, with only limited exceptions, the sourcing of the raw materials. ${ }^{14}$ Moreover, and more importantly for the sake of the argument put forward in this article, PGI accepts a mere reputational link that must be essentially, but not exclusively, attributable to the geographical origin of the product.

It is not possible to analyse in depth the nature of this linking factor, as that would exceed the purpose of this article. Here it is enough to explain that "reputation" has always been substantively and theoretically distinct from the elements that determine the terroir link. In particular, the first form of reputational element has been the "market reputation". This consists of the image provided by a product that raises specific expectations in the minds of consumers regarding the characteristics and the origin of that product. ${ }^{15}$ However, the reputational element is also linked to factors that do not merely depend on the opinions of consumers, such as the history of the product and its current social and economic importance. ${ }^{16}$ Furthermore, the PGI origin link can also consist of qualitative elements or "other characteristics". Setting aside the latter factor, the nature of which is unclear, analysis of the specifications shows that very often the "qualitative" element takes the form of natural factors that determine the physical characteristics of the good. Hence it is not so different from the traditional components of the terroir link. ${ }^{17}$

In general, however, the difference between PDOs and PGIs is usually described as a clash between the logic of terroir and that of reputation. ${ }^{18}$ This dual approach descends from the historical origins of the two quality schemes. In particular, as mentioned in the introduction, PDO descends from national and international systems based on the concept of terroir. By contrast, PGIs are essentially the transference into EU law of traditions of countries, such as the U.K. and Germany, which had not adopted a sui generis GI regime before 1992. Therefore, with different nuances, they used to protect geographical names mainly through the law of unfair competition, passing off and/or false advertising, i.e. systems based on the

\footnotetext{
14 See Art. 5(1)(c) of the Regulation.

15 See Gangjee (2012), pp. 225-237.

16 For more information on this specific issue, see Gangjee (2017), pp. 54-59 and Gangjee (2012), pp. 235-237. See also Zappalaglio (2018), pp. 144-146.

17 Natural factors typical of the terroir link can be found in PGI specifications in approximately $55 \%$ of cases. See Zappalaglio, supra note 16, p. 183.

18 See, Gangjee (2012), pp. 225-226.
} 
perception of consumers and on the need to ensure truth-telling in the market place. ${ }^{19}$ The next section will analyse the origins and the predecessors of the PDO quality scheme, thus highlighting why the Proposal is inconsistent with the history and the evolution of this quality scheme.

\subsection{The Origins of PDO}

Both PDO and its historical predecessors have always been based on a balance between human and physical elements. As mentioned in the introduction, this quality scheme descends from the concept of Appellation d'Origine Contrôllée, which was introduced in France in 1935. A complete overview of the history of this origin label would exceed the scope of this article, therefore only an outline will be provided. ${ }^{20}$

The concept of AOC started to be theorised in 1927, when the French Parliament realised that the only reliable way to protect the producers of high-quality French wine was to link law and agronomy, ${ }^{21}$ thus ensuring a one-to-one correspondence between a product and its place of origin based on the natural characteristics of the designated area. This was a step forward compared to the previous systems, which, as mentioned above, were, generally speaking, based on unfair competition standards, and, therefore, aimed only at ensuring the formal correctness on the marketplace, with modest results, ${ }^{22}$ rather than trying to establish a substantive origin link. The law of $1935^{23}$ did not define the AOC, limiting itself to introducing the Comité National des Appellations d'Origine (CNAO), nowadays known as Institut National des Appellations d'Origine (INAO), which was the first national authority in charge of analysis of the applications filed by local associations of producers (syndacats). However, the discussions in the French Parliament, as well as the statements of the promoters of the concept of AOC, make it clear that the system had to be based on an origin link featuring both the natural features of the soil and of the environment, what is known as the terroir, as well as human techniques and know how. ${ }^{24}$

The nature of the origin link for the "Appellation of Origin" became explicit in 1958, when it was defined and enshrined into the international legal framework by

\footnotetext{
19 The best account of the evolution of the sui generis systems for the protection of Indications of Geographical Origin at the international and European levels can be found in Gangjee (2012), pp. 96-123. See also Le Goffic (2010) pp. 91-172; Zappalaglio, supra note 16, pp. 107-110.

${ }^{20}$ For more information on the concept and the story of AOC, see: Gangjee (2012), pp. 108-109; Le Goffic (2010), pp. 6-16; and Loubère (2014), pp. 113-126. See also INAO (1985), pp. 19-22 and Zappalaglio, supra note 16, pp. 21-30.

${ }^{21}$ Capus (1947), pp. 22-24.

${ }^{22}$ The French scholar Humbert has stated that, de facto, the system was unable to protect fine products. See Humbert (2011), p. 98.

${ }^{23}$ Decret-Loi 30 Juillet 1935 "Défense du marché des vins et regime économique de l'alcool', JORF 31 Juillet 1935.

${ }^{24}$ This is confirmed by the memoirs of the French Minister and oenologist Joseph Capus, who is considered to be the father of the AOC, see Capus, supra note 21, p. 10. See also Loubère, supra note 20, p. 123 .
} 
the Lisbon Agreement. This, even after its recent update completed in 2015 through the Geneva Act, ${ }^{25}$ defines $\mathrm{AO}$ in the following way:

"appellation of origin" means the geographical denomination of a country, region, or locality, which serves to designate a product originating therein, the quality or characteristics of which are due exclusively or essentially to the geographical environment, including natural and human factors. ${ }^{26}$

This became the standard definition of $\mathrm{AO}$ and was adopted by different countries, for example France (in 1966). ${ }^{27}$ Eventually this conception of AO was enshrined, almost verbatim, in Regulation 2082/1992, ${ }^{28}$ i.e. the first EU sui generis GI protection regime for agricultural products and foodstuffs. In particular, Art. 2 thereof reads as follows:

designation of origin means the name of a region, a specific place or, in exceptional cases, a country, used to describe an agricultural product or a foodstuff:

[...]

- the quality or characteristics of which are essentially or exclusively due to a particular geographical environment with its inherent natural and human factors, and the production, processing and preparation of which take place in the defined geographical area.

This recounting of the historical origins of PDO, conducted through a description of its forbearers (AOC and $\mathrm{AO}$ ), shows that this quality scheme descends from a clear legal tradition. It has constantly considered the natural and the human factors as equally important when determining the existence of an origin link capable of justifying the granting of protection. Therefore proposing an amendment of this substantive importance requires strong practical and theoretical justifications. Unfortunately, those seem to be weak in the case at hand, as it will be shown in the next section.

\section{Construing the Justifications for the Proposal}

The Commission does not explain specifically the rationale behind the proposal to amend Art. 5(1)(b), thus restricting the importance of the human contribution in the specification of a PDO product. It is, therefore, difficult to understand the exact justification for this proposal, all the more because, as shown earlier, the model of PDO that would result from the amendment would be unprecedented and apparently

\footnotetext{
${ }^{25}$ See supra note 8 and infra Section 4.3.

${ }^{26}$ Art. 2(1)(i) of the Geneva Act of the Lisbon Agreement (2015). Emphasis added.

${ }^{27} C f$. Loi no ${ }^{\circ} 66-482$ du 6 Juillet 1966 modifiant e complétant la loi du 6 Mai 1919 relative à la protection des Appellations d'Origine, JORF 7 Juillet 1966, 5781, 26. "Constitue une Appellation d'Origine la dénomination d'un pays, d'une région ou d'une localité servant à désigner le produit qui en est originaire et don la qualité ou les caractères sont dus au milieu géographique comprenant des facteurs naturels et des facteurs humains".

28 Supra note 9.
} 
inconsistent with previous EU legislation, as well as being inconsistent with the current international framework.

However, in the Proposal the Commission lays down some general principles that should constitute the foundation of the reformed EU sui generis GI system. In particular, it states that the entire CAP should be modernised and simplified. ${ }^{29}$ Accordingly, with regard to GIs it concludes that:

It is $[\ldots]$ proposed to amend current rules on GIs [...] aiming at a simpler GI system, faster registration of geographical indications and more efficient approval of amendments to product specifications. These changes aim to a simplified GI system that would be more understandable to consumers, easier to promote and would reduce administrative costs of managing the system. ${ }^{30}$

It can be ruled out that the proposed amendments would make the GI regime "more understandable to consumers" or that they would make the system less expensive. However, it is reasonable to hypothesise that this proposal has been put forward in line with the stated goal of achieving simplification. Indeed, as mentioned above, ${ }^{31}$ the natural element is the one that characterises the PDO quality scheme, whereas a PGI can, but does not necessarily have to, include a reference to terroir. Therefore the Commission seems to be suggesting that as the terroir link is the distinguishing element of PDOs, it should be considered as the central factor to be proved, thus simplifying the specification, which would include a reference to human elements only "when relevant". This strategy, however, will probably be ineffective, for a number of reasons, both substantive and practical, that will be analysed in the following section.

\section{Why the Proposal Should Be Reconsidered}

\subsection{The Narrow Approach to GI Protection was Abandoned in 1992}

The idea of adopting a narrow approach to the concept of sui generis GIs is not new. Indeed, before Regulation 2081/1992 the ECJ considered all forms of protection of geographical names that were not based on a purely physical origin link as measures having an effect equivalent to a quantitative restriction of trade. For instance, in the Sekt case $(1975)^{32}$ the ECJ held that:

These appellations only fulfil their specific purpose if the product which they describe does in fact possess qualities and characteristics which are due to the fact that it originated in a specific geographical area. As regards indications of origin in particular, the geographical area of origin of a product must confer on it a specific quality and specific characteristics of such a nature as to distinguish it from all other products. ${ }^{33}$

\footnotetext{
29 See the Proposal, supra note 1 , p. 1.

30 Ibid, p. 124.

31 Supra, Section 2.1.

32 Case 12-74 Commission v. Germany [1975] ECR 181 (Sekt). See also Mantrov (2014), para. 5.3.

33 Sekt (n 69), issue 2 para. 7.
} 
This position was reversed in 1992. Indeed, Regulation 2081/1992 introduced not only a definition of PDO that includes both natural and human factors but also the PGI scheme that is mainly based on reputation, that is to say, as mentioned above, an origin link strongly related to human actions (traditional practices, etc.) and opinions (market reputation). ${ }^{34}$ Furthermore, this new trend was also confirmed by the famous ECJ decision in the Exportur case, where it was held that:

Such names may [...] enjoy a high reputation amongst consumers and constitute for producers established in the places to which they refer an essential means of attracting custom. They are therefore entitled to protection. $^{35}$

Thus the beginning of the EU sui generis GI regime was marked by the introduction of a broader way of conceiving the origin link, in which even the subjective opinion of consumers can justify the granting of a GI. A fortiori, it is reasonable to state that the human element which composes the PDO origin link is perfectly consistent with the legal frame that has been being developed in the EU since 1992. Narrowing it down, highlighting only the natural element would recall the idea of protection of geographical names which was developed decades ago by the ECJ. This is not easy to justify, because, before the introduction of the EU sui generis GI regime, the assessment of the national rules for the protection of geographical names was generally conducted on the basis of the rules governing the free movement of goods. ${ }^{36}$ This era ended with the introduction of the EU sui generis GI regime.

Therefore the idea of adopting a restrictive definition of indication of geographical origin was abandoned with the introduction of Regulation 2081/1992. Thus the amendment proposed by the Commission contrasts with the evolution of the nature of the EU GI regime over the last few decades. Furthermore, this substantive change to the definition of PDO seems to conceal an outdated idea of the concept of terroir, as will be shown in the next section.

\subsection{Terroir Is a Mix of Natural and Human Factors}

The idea of turning the human element mentioned in the definition of PDO into an optional element should be reconsidered, as it is weak from the theoretical perspective and may be pleonastic in practice. Indeed, the terroir link that characterises PDOs and, in general, the entire family of Appellations of Origin is necessarily a mix of human and natural factors. Moreover, this concept has become more and more spiritualised. ${ }^{37}$

\footnotetext{
34 Supra, Section 2.1.

35 Case C-3/91 Exportur SA v. LOR SA and Confiserie du Tech SA [1992] ECR I-05529 (Exportur), para. 28.

${ }^{36}$ For another example, see Case 16/83 Criminal proceedings against Karl Prantl [1984] ECR 1299 (Bocksbeutel).

37 For a discussion on the spiritualisation of terroir and, in particular, on the interesting concept of "psychogeography", see Parker (2015), pp. 155-160.
} 
Regulation 1151/2012 does not define the concept of terroir and also does not mention it directly. ${ }^{38}$ However, it does that indirectly when it states that a PDO product must be linked to its area of origin through both natural and human elements. As mentioned above, ${ }^{39}$ this provision coincides with Art. 2(1)(i) of Lisbon Agreement. ${ }^{40}$ Moreover, this concept has been defined by some organisations that even emphasise the role of the human intervention over the mere physical/ environmental factor, for instance the French INAO authoritatively defines this origin link as:

A geographical area with defined boundaries where a human community generates and accumulates across its history a collectively developed knowledge of production based on a system of interactions between a physical and a biological environment. The social and technical itineraries involved confer "typicality", reveal originality and lead to a reputation for a product originating from that geographical area. ${ }^{41}$

Indeed, the substantive point that the Commission should take into consideration is that terroir has been predominantly construed, over the last sixty years at least, as a mix of physical and human factors. In particular, the latter is generally associated with the local technical know-how that characterises the production of the given product. $^{42}$

It is not possible here to explain in depth the historical evolution of this concept. ${ }^{43}$ However, it is expedient to remember that French geographer Roger Dion stressed the importance of the human intervention over the soil as early as the 1940s. ${ }^{44}$ This marked the beginning of the modern understanding of terroir that reversed the previous, "narrow", version of this concept that was generally based on a naturalistic vision, according to which the word meant just "soil", sometimes in a pejorative sense. $^{45}$

Today, as the above-mentioned definitions show, this reductive version of terroir is not dominant anymore and, despite emerging from time to time, especially in the

\footnotetext{
38 The importance of the human is, however, stressed in the Preamble. See Regulation 1151/2012, Recital 1.

39 Supra, Section 2.2.

40 This approach has also been endorsed by the WIPO. See WIPO Standing Committee on the Law of Trademarks, Industrial Designs and Geographical Indications, "Geographical Indications" (Geneva 28 April - 2 May 2003) para. 27-28.

41 Original text: "Un terroir est un espace géographique délimité, dans lequel une communauté humaine, construit, au cours de son histoire, un savoir collectif de production, fondé sur un système d'interactions entre un milieu physique et biologique, et un ensemble de facteurs humains. Les itinéraires sociotechniques ainsi mis en lieu, révèlent une originalité, confèrent une typicité, et aboutissent à une notorieté pour un bien originaire de cet espace géographique." INAO, Guide Du Demandeur (Novembre 2017), 26. A similar definition has been provided by UNESCO, see Terroir \& Cultures, "The future needs terroirs" (29 January 2010).

42 Bérard et al. (2000), p. 165. For an authoritative collection of definitions of terroir, see Casabianca et al. (2011).

43 See Gangjee (2012), pp. 83-92; Bérard (2016), pp. 73-80 and Zappalaglio, supra note 16.

44 Dion (1990), pp. 225-226. First published in Publications de la Société Géographique de Lille (1946).

45 Matthews (2015), pp. 160-162; Zappalaglio, supra note 16, pp. 40-42.
} 
jargon of viticulture, ${ }^{46}$ it is criticised by leading scholars in this field; Laurence Bérard, for instance, describes it as "simplistic 47 “. This observation is absolutely correct since, nowadays, it is indisputably recognised that the human element must always be present. ${ }^{48}$ This is due to the fact that the natural and human elements are different sides of the same coin. Indeed, a terroir product is the result of the effects of a specific physical/natural environment over a geographical area. These elements determine the quality of the raw materials and influence the production process as a whole. However, it is the human contribution, that is to say the know-how, which in practice makes the product what it is. ${ }^{49}$ In fact, only native vegetation and other spontaneous goods and raw materials can be considered products that do not depend on any human intervention.

Different case studies show that the environment pushes communities of human to develop a specific know-how, which is also deeply influenced by the socio-economic features of the area. ${ }^{50}$ Just to give one example, ${ }^{51}$ the French and Swiss Gruyère cheese has been made for centuries by groups of breeders and cheese-makers in areas that are difficult to cultivate but suited to dairy herds. Traditionally this cheese was an excellent way to preserve milk and constituted a supply of food during the winter. Thus the geographical environment pushed the human communities to make cheese for their own sustenance and the natural factors played a role in determining the quality of the product. However, the human element also essentially contributes to the product. In the case of Gruyère the management of the production of the cheese was regulated by customary rules. In particular, one cheese-maker was hired by all of the breeders in order to make the product. That man therefore had at his disposal a huge quantity of milk. This is why, even today, the wheels of Gruyère are very large and heavy. ${ }^{52}$ Thus it is possible to observe that the "Gruyère" product, which is protected as a PGI in France and an AOC in Switzerland, is a result of both natural and human factors and that the latter and the former are closely intertwined.

Therefore the proposal seems to be based on a theoretically flawed idea of terroir. In any event, it is highly likely that this amendment to the definition of PDO will simply prove to be pleonastic in the practice of EU GI law. That is due to the fact that the human element will almost always be relevant in order to describe the terroir link between a product and its place of origin. Indeed, as has already been argued, this element is a necessary part of the origin link and it is essential in order to accurately locate a product in a specific geographical area. Moreover, the specifications of registered PDOs regularly include not only elements related to the human element of terroir, such as local technical know-how, ${ }^{53}$ but also others

\footnotetext{
${ }^{46}$ For a recent example of this approach, see Morlat et al. (2001). For an older example, see Marres (1950).

47 Bérard (2016), p. 77.

48 Gangjee (2012), p. 223.

49 Bérard and Marchenay (2008), p. 9.

${ }^{50}$ For a revealing study, see Barjolle et al (1998), pp. 8-19.

51 Barjolle et al, supra note 50, pp. 15-17.

52 Ibid.

53 Bérard et al., supra note 42, 165.
} 
generally associated with the reputational link that characterises PGIs. In particular, human factors, such as the history of the given product, its socio-economic importance and its market reputation, appear in more than $70 \%$ of PDO specifications. ${ }^{54}$

Therefore, on the one hand this amendment will make the origin link weaker and, on the other hand, it is highly likely that it will not have any substantive impact on the practice of EU GI law. This point will be discussed in more detail below.

\subsection{The Alleviation of the Human Factor Will Weaken the Foundations of PDO}

As mentioned in the introduction to this article, the EU Parliament has stated that the proposed amendment analysed herein would negatively "affect the protection of products at international level where opponents will often evoke similarities in the natural and geographical environment to undermine the specificity of designations of origin". The author would argue that this observation is correct. Indeed, the concept of terroir, and the rationale of sui generis GI rules altogether, is often criticised by countries which do not accept these regimes of protection of indications of geographical origin. The most famous example, although not the only one, is the criticism from the United States. ${ }^{55}$ The amendment would weaken the foundations of PDO, thus making this quality scheme less credible.

The arguments of the critics of GIs, according to whom terroir is a romanticised concept that disguises monopoly rents and agricultural subsidies, are well known. ${ }^{56}$ It is equally well known that the link between the place of origin and the quality of a product is often accused of being largely exaggerated and used as a device for protectionism and for appropriating common food names. ${ }^{57}$ More specifically, the pure natural link has been strongly attacked; for instance, some studies have forcefully criticised the scientific soundness of the physical terroir link as well as its relevance in the field of agronomy. ${ }^{58}$

These criticisms are not irrefutable. ${ }^{59}$ However, the proposed amendment would make the rationale of PDO weaker. Indeed, these objections can be better overcome by accepting the dual concept of terroir. This concept, as shown in the previous subsection, is not only the most widespread and theoretically sound version of this linking factor, but it also enables one to better identify the origin of the product and its distinguishing features. In fact, the natural environment is an anchor that

\footnotetext{
54 Zappalaglio, supra note 16, p. 181.

55 For a summary of the contrasts between the EU and the US on GIs, see Le Goffic and Zappalaglio (2017), pp. 35-37.

56 For all see Hughes (2006), pp. 339-341. See also Hughes (2017).

57 Watson (2016).

58 For an entire monography on this issue, see Matthews, supra note 45.

59 Several studies, focusing on individual goods, have demonstrated that the organoleptic qualities of the agricultural products are indeed influenced by the characteristics of the environment. However, this is not always enough to justify the existence of an exclusive and non-replicable link that can be tested and described in scientific terms, as even top scholars, who are certainly not hostile to GIs, have had to admit. See Barjolle et al. (2011), p. 96. For a focus on the identifications methods of the terroir link, see, inter alia, Allaire et al. (2011), pp. 1-7.
} 
physically locates a product in a specific context. ${ }^{60}$ However, it is not always enough to justify the existence of an exclusive link between a product and a place, because, as the Parliament rightfully points out, the uniqueness of this kind of link can be opposed and denied. Therefore, it must not be overlooked that, with only the exception of native goods, it is the human element that makes the products recognisable and unique and that this is widely recognised by the best international literature, ${ }^{61}$ and also demonstrated by various case studies. ${ }^{62}$

To sum up, the Parliament is right when it argues that this proposed amendment would weaken PDOs. Indeed, without the human element, the concept of terroir itself becomes weaker and less capable of justifying, in an international environment, the protection of a specific product in light of its allegedly unique features.

\subsection{The Proposed Amendment Seems Inconsistent with the Position that the Commission is Supporting at the International Level}

On 20 May 2015 the WIPO Diplomatic Conference for the adoption of a new act of the Lisbon Agreement ${ }^{63}$ adopted the Geneva Act. ${ }^{64}$ This treaty aims at enhancing and updating the existing system for the international registration of AOs. ${ }^{65}$ It has not come yet into force, as to date only two countries (Cambodia and Côte d'Ivoire) have deposited instruments of ratification and at least five are needed to do so. However, it is highly likely that the Geneva Act will come into force in the future, as the EU Commission has already recommended that the EU should join it and, moreover, seven EU Member States are parties to the Lisbon Agreement. ${ }^{66}$ An indepth description of this international treaty would exceed the scope of this article, here it is enough to focus on two points.

First of all, the definition of AO that, as mentioned above, ${ }^{67}$ was introduced in 1958 and that almost completely overlaps with that of PDO has not been modified. Thus it is unclear why the Commission is, at the same time, proposing an

\footnotetext{
$\overline{60}$ Gangjee (2012), pp. 141-142.

61 See, inter alia, Bérard and Marchenay (1996), Bérard and Marchenay (2006), and Bérard and Marchenay (1995).

62 See, supra Section 4.2 and Zappalaglio supra note 16, pp. 241-247.

63 The WIPO, Diplomatic Conference for the Adoption of a New Act of the Lisbon Agreement, available at https://www.wipo.int/meetings/diplomatic_conferences/2015/en/.

64 The Geneva Act of the Lisbon Agreement on Appellations of Origin and Geographical Indications and Regulations Under the Geneva Act of the Lisbon Agreement on Appellations of Origin and Geographical Indications (LI/DC/19, 20 May 2015). For more information, see the WIPO (2018a) The Main Provisions and Benefits of the Geneva Act of the Lisbon Agreement.

65 The WIPO (2018a) The Main Provisions and Benefits of the Geneva Act of the Lisbon Agreement (2015).

66 The European Commission, Proposal for a Decision: EU Accession to the Geneva Act of Lisbon Agreement on Appellations of Origin and Geographical Indications, available at https://ec.europa.eu/info/ law/better-regulation/initiatives/ares-2017-6308027_en and the European Commission, The EU to Join the Geneva Act of the Lisbon Agreement to Better Protect GIs (European Commission, 27 July 2018) https://ec.europa.eu/info/news/eu-join-geneva-act-lisbon-agreement-better-protect-gis-2018-jul-27_en.

67 Supra, Section 2.2.
} 
amendment to the latter while supporting the Geneva Act, which does not affect the former. The second point instead concerns one of the most discussed innovations introduced by way of this reform, i.e. the extension of the protected subject matter of the treaty to Geographical Indications and not only to Appellations of Origin. Specifically, the scope of the treaty has now been extended to:

any indication protected in the Contracting Party of Origin consisting of or containing the name of a geographical area, or another indication known as referring to such area, which identifies a good as originating in that geographical area, where a given quality, reputation or other characteristic of the good is essentially attributable to its geographical origin. ${ }^{68}$

Thus the EU Commission is explicitly endorsing an international regime which has been broadened and which now encompasses a model of protection of indications of geographical origin that accepts the reputational link. As outlined above $^{69}$ the reputational link tends to be very broad and linked to human intervention, ${ }^{70}$ ranging from market reputation to the image of the given product resulting from its history. However, the Proposal put forward by the Commission is aimed at limiting the human element while highlighting the role of the natural factors only. That is inconsistent with the recent innovations at international level which this European institution itself is endorsing and makes it hard to understand and justify the policy underpinning the proposed amendment.

\section{Conclusion}

On 1 June 2018 the EU Commission presented the Proposal, covering the reform of the CAP, including different aspects of the EU sui generis GI rules. In particular, this institution has put forward an amendment to the definition of PDO. Traditionally, this quality scheme and its historical predecessors (specifically the French AOC and the AO model), enshrined in the Lisbon Agreement, have always been characterised by an origin link consisting of both natural and human factors, often known as terroir. The Commission instead proposes to turn the latter element into an optional factor to be taken into consideration only "when relevant". Supposedly this amendment is aimed at enhancing clarity and simplicity within the EU GI system. Responding to the Commission, the Committee on Agriculture and Rural Development of the EU Parliament has expressed doubts as to the convenience of this change.

With regard to that specific proposal, the present opinion invites the Commission to reconsider the proposed reform. Indeed, on the one hand this seems to be based on a disputable notion of the PDO origin link; on the other, it is likely to have a modest impact on the structure of applications, as the human element will always be "relevant" in order to establish a convincing terroir link. Thus, the goals that the

\footnotetext{
$\overline{68}$ Lisbon Agreement (2015), Art. 2(1)(ii).

69 Supra, Section 2.1.

70 See Gangjee (2012), pp. 235-237.
} 
Commission is determined to pursue, i.e. the simplification of the system and the acceleration of the registration procedure, will hardly be achieved.

In more detail, this opinion shares the doubts of the EU Parliament and argues that this specific amendment concerning the definition of PDO should not be included in the future reform of Regulation 1151/2012, because: (1) it is based on an idea of GI protection that was discarded with the introduction of the EU sui generis GI regime in 1992; (2) it adopts a disputable concept of terroir; (3) it could potentially weaken the foundations of PDO and makes such less justifiable in front of third countries; and (4) it is apparently inconsistent with the recent reform of the Lisbon Agreement that the Commission itself is endorsing and recommending to the EU Member States.

Acknowledgements Open access funding provided by the Max Planck Society.

Open Access This article is distributed under the terms of the Creative Commons Attribution 4.0 International License (http://creativecommons.org/licenses/by/4.0/), which permits unrestricted use, distribution, and reproduction in any medium, provided you give appropriate credit to the original author(s) and the source, provide a link to the Creative Commons license, and indicate if changes were made.

\section{References}

Allaire G, Casabianca F, Thévenod-Mottet E (2011) Geographical origin: a complex feature of agro-food products. In: Barham E, Sylvander B (eds) Labels of origin for food: local development, global recognition. CABI, Wallingford

Barham E (2002) Towards a theory of values-based labeling. Agric Hum Values 19:349

Barham E (2003) Translating terroir: the global challenge of French AOC labelling. J Rural Stud 19:127

Barham E (2016) Translating terroir revisited: the global challenge of French AOC labeling. In: Gangjee D (ed) Research handbook on intellectual property and geographical indications. Edward Elgar Pub, Cheltenham

Barjolle D, Boisseaux S, Dufour M (1998) Le Lien Au Terroir: Bilan Des Travaux de Recherce. Institut d'économie rurale, Bamako

Barjolle D, Sylvander B, Thévenod-Mottet E (2011) Public policies and geographical indications. In: Barham E, Sylvander B (eds) Labels of origin for food: local development, global recognition. CABI, Wallingford

Bérard L (2016) Terroir and the sense of place. In: Gangjee D (ed) Research handbook on intellectual property and geographical indications. Edward Elgar Pub, Cheltenham

Bérard L, Marchenay P (1995) Lieux, Temps et Preuves: La Construction Sociale Des Produits de Terroir. 24 Terrain

Bérard L, Marchenay P (1996) Tradition, regulation and intellectual property: local agricultural products and foodstuffs in France. In: Brush SB, Stabinsky D (eds) Valuing local knowledge: Indigenous Peoples and Intellectual Property Rights, Island Press, Covelo, CA

Bérard L, Marchenay P (2006) Local products and geographical indications: taking account of local knowledge and biodiversity. UNESCO, Paris

Bérard L, Marchenay P (2008) From localised products to geographical indications: awareness and action. Centre national de la recherche scientifique, Paris

Bérard L, Beucherie O, Fauvet M, Marchenay P, Monticelli C (2000) Les Facteurs Historiques, Culturels, Économiques et Environnementaux Dans La Délimitation Des Zones IGP. In: Sylvander B, Barjolle D, Arfini F (eds) The socio-economics of origin labelled products in agri-food supply chains: spatial, institutional, and co-ordination aspects. Actes et Communications 
Capus J (1947) L'Évolution de La Législation Sur Les Appellations d'origine: Genèse Des Appellations Contrôlées. INAO

Casabianca F, Sylvander B, Noël Y (2011) Terroir et Typicité: Un Enjeu de Terminologie Pour Les Indications Géographiques. In: Delfosse C (ed) La mode du terroir et les produits alimentaires. Les Indes Savantes, Paris

Dion R (1990) Le Paysage et La Vigne. Essais de Géographie Historique. Bibliothèque Historique Payot

Gangjee D (2012) Relocating the law of geographical indications. Cambridge University Press, Cambridge

Gangjee D (2017) From geography to history: geographical indications and the reputational link. In: Calboli I, Ng-Loy WL (eds) Geographical indications at the crossroads of trade, development, and culture in the Asia-Pacific. Cambridge University Press, Cambridge

Hughes J (2006) Champagne, feta and bourbon: the spirited debate about geographical indications. Hastings Law J 58:299

Hughes J (2017) The limited promise of geographical indications for farmers in developing countries. In: Calboli I, Ng-Loy WL (eds) Geographical indications at the crossroads of trade development and culture. Cambridge University Press, Cambridge

Humbert F (2011) L'INAO, de ses origines à la fin des années 1960. Université de Bourgogne

INAO (1985) Une Réussite Française: L’Appellation d'Origine Contrôlée. INAO, Paris

INAO (2017) Guide Du Demandeur

Le Goffic C (2010) La Protection Des Indications Géographiques. LexisNexis, New York

Le Goffic C, Zappalaglio A (2017) The role played by the US Government in protecting geographical indications. World Dev 98:35

Loubère LA (2014) The wine revolution in France: the twentieth century. Princeton University Press, Cambridge

Mantrov V (2014) EU law on indications of geographical origin. Springer, Berlin

Marres P (1950) La Vigne et Le Vin En France. Librairie Armand Colin, Paris

Matthews MA (2015) Terroir and other myths of winegrowing. University of California Press, Berkeley

Morlat R, Barbeau G, Asselin C (2001) Facteurs Naturels et Humains Des Terroirs Viticoles Français: Méthode d'étude et Valorisation. Études et Recherches sur les Systèmes Agraires et le Développement 32:111

Parker T (2015) Tasting French terroir: the history of an idea. University of California Press, Berkeley

Watson WK (2016) Reign of terroir: how to resist Europe's efforts to control common food names as geographical indications. Cato Institute. Policy analysis No. 787. https://www.cato.org/publications/ policy-analysis/reign-terroir-how-resist-europes-efforts-control-common-food-names

WIPO (2018a) Main provisions and benefits of the Geneva Act of the Lisbon Agreement (2015)

WIPO (2018b) Diplomatic Conference for the adoption of a new act of the Lisbon Agreement. https:// www.wipo.int/meetings/diplomatic_conferences/2015/en/

Zappalaglio A (2018) The why of geographical indications: the transformation of the link between the product and its place of origin in Europe. University of Oxford, Oxford. https://ora.ox.ac.uk/objects/ uuid:d7124003-81b5-4d7b-8c27-eba29c8a3d24

Publisher's Note Springer Nature remains neutral with regard to jurisdictional claims in published maps and institutional affiliations. 